\title{
Changes in Procoagulant and Fibrinolytic Gene Expression during Bleomycin-induced Lung Injury in the Mouse
}

\author{
Mitchell A. Olman, ${ }^{\star \neq \| 1}$ Nigel Mackman, ${ }^{\S}$ Candece L. Gladson," Kenneth M. Moser, ${ }^{\ddagger}$ and David J. Loskutoff* \\ Departments of *Vascular Biology and ${ }^{8}$ Immunology, The Scripps Research Institute, La Jolla, California 92037; ${ }^{\ddagger}$ The Division of \\ Pulmonary and Critical Care Medicine, University of California, San Diego, San Diego, California 92037; and the "Departments of \\ Pathology and 'Medicine, University of Alabama, Birmingham, Alabama 35294
}

\begin{abstract}
Bleomycin-induced lung injury is an established murine model of human pulmonary fibrosis. Although procoagulant molecules (e.g., tissue factor [TF]) and fibrinolytic components (e.g., urokinase [u-PA] and type 1 plasminogen activator inhibitor [PAI-1]) have been detected in alveolar fluid from injured lungs, the origin of these molecules remains unknown. We therefore examined the expression of procoagulant and fibrinolytic components in relation to the distribution of parenchymal fibrin in bleomycin-injured lungs. Extravascular fibrin localized to the alveolar and extracellular matrix in injured lung tissue. Injured lung tissue extracts contained elevated levels of PAI-1 activity and decreased levels of u-PA activity. Whole lung PAI-1 and TF mRNAs were dramatically induced by lung injury. In situ hybridization of injured lungs revealed that PAI-1, u-PA, and TF mRNAs were induced within the fibrin-rich fibroproliferative lesions, primarily in fibroblast-like and macrophagelike cells, respectively, while TF mRNA was also induced in perilesional alveolar cells. Taken together, these observations suggest that the induction of PAI-1 and TF gene expression plays an important role in the formation and persistence of extracellular fibrin in bleomycin injured murine lungs. (J. Clin. Invest. 1995. 96:1621-1630.) Key words: fibrinolysis - tissue factor • pulmonary fibrosis • in situ hybridization
\end{abstract}

\section{Introduction}

Bleomycin-induced lung injury in animals is a well established histological and biochemical model of human pulmonary fibro-

Dr. Mitchell A. Olman's current address is University of Alabama at Birmingham, Division of Pulmonary and Critical Care Medicine, 1900 University Blvd., Birmingham, AL 35294.

Address correspondence to David J. Loskutoff, The Scripps Research Institute, Department of Vascular Biology, 10666 North Torrey Pines Road, Mail Code CVB-3, La Jolla, CA 92037. Phone: 619-5547125; FAX: 619-554-6404.

Received for publication 21 January 1994 and accepted in revised form 5 June 1995.

1. Abbreviations used in this paper: IT, intratracheal; PA, plasminogen activator; PAI-1, type 1 PA inhibitor; TF, tissue factor; t-PA, tissue type PA; u-PA, urokinase-like PA.

J. Clin. Invest.

(c) The American Society for Clinical Investigation, Inc.

$0021-9738 / 95 / 09 / 1621 / 10 \quad \$ 2.00$

Volume 96, September 1995, 1621-1630 sis (1-3). In strain-sensitive mice, a single intratracheal (IT) ${ }^{1}$ instillation of bleomycin results in a neutrophilic and lymphocytic acute pan-alveolitis in the first week (4). These changes are followed by the clearing of the alveolar inflammatory cells, with subsequent fibroblast proliferation and the synthesis of extracellular matrix protein eventually leading to peribronchial pulmonary fibrosis $(5,6)$. The evolution of these fibroproliferative lesions occurs within $3 \mathrm{wk}$ of the instillation of bleomycin.

Current concepts about the nature of the resolution process that takes place 2-3 wk after bleomycin-induced lung injury suggest that the final outcome depends on the severity and the protraction of the early injury $(1,2)$. Furthermore, it has been suggested that the tissue repair process occurs along an insoluble matrix composed of fibrin and both plasma-derived and cellsynthesized matrix proteins $(7,8)$. This matrix-bound fibrin and its soluble degradation products may, in turn, modulate the tissue repair response by altering vascular tone, stimulating fibroblast and neutrophil migration, and enhancing adhesion and spreading of both endothelial cells and fibroblasts (9-12). Moreover, in the fibrinous exudate that forms after acute lung injury, other fibrin-bound glycoproteins (e.g., fibronectin) may act as potent matrix secretogogue(s) for fibroblasts (13), thereby altering the final extent of fibrosis. These concepts gain additional support by the recent demonstration of fibrin in the alveolar lining of lung biopsy tissue from patients with idiopathic pulmonary fibrosis (14). Taken together, these observations emphasize the need to identify the factor(s) responsible for fibrin deposition and clearance after lung injury.

Tissue factor (TF) is the primary cellular initiator of the coagulation protease cascades (15). High-affinity binding of factors VII/VIIa to TF activates factors IX and X by limited proteolysis (16). Studies of bronchoalveolar lavage fluid suggest that TF functions as the initiator of the coagulation cascade in the alveolar space as well (17). In addition to procoagulant activity, normal alveolar fluid possesses measurable fibrinolytic activity (18). The process of fibrinolysis in the alveolar space is generally thought to be regulated primarily at the level of the activation of this system by plasminogen activators (PA)s, as plasminogen is ubiquitous in lung tissue (19). The major PA responsible for this action in many extravascular tissues is urokinase (u-PA), although tissue type PA (t-PA) may also be present $(20,21)$. These PAs can be specifically inhibited by type 1 plasminogen activator inhibitor (PAI-1), a 50-kD glycoprotein that is a member of the serpin superfamily of genes (22). The potential relevance of the PA/PAI-1 system to extracellular matrix remodeling after lung injury is underscored by its highly regulated expression in diverse tissue remodeling processes such as ovulation, breast gland involution, and embryogenesis (23). Moreover, recent reports from our laboratory have described alterations in the levels of pulmonary TF and PAI-1 
mRNAs after gram-negative bacterial endotoxin induced lung injury in mice $(24,25)$.

Within $1 \mathrm{wk}$ after IT bleomycin in the rat, bronchoalveolar lavage fluid TF activity is enhanced, while u-PA-mediated fibrinolytic activity is inhibited, in part, by increases in PAI-1 (26). These observations suggest that the extent of extravascular fibrin deposition during lung injury may reflect the balance of the actions of TF and the various components of the fibrinolytic system on plasma-derived fibrinogen (27). However, the origins of the TF and PAI-1 found in bronchoalveolar lavage fluid are unknown, and the lavage procedure itself may cause the fragmentation and release of TF-containing plasma membrane vesicles from alveolar cells thereby complicating extrapolation to the tissue level (17). Little is known regarding the localization of fibrin to fibroproliferative phase (i.e., 14 and $21 \mathrm{~d}$ ) lesions, or about the tissue level expression of TF, u-PA, t-PA, and PAI-1 in bleomycin-injured lungs, despite the alveolar fluid findings. In this report, we characterize the origin and potential role of TF, PAI-1, and the PAs in the repair process that follows bleomycin-induced lung injury in mice. Pulmonary TF and PAI1 mRNAs were found to be specifically induced within fibrinrich fibroproliferative lesions suggesting an important role for fibrin persistence in the formation of these lesions. Pulmonary u-PA activity localized to the parenchyma and u-PA mRNA induction localized to fibroproliferative lesions, however, pulmonary u-PA activity was found to be suppressed in association with an enhanced PAI-1 activity.

\section{Methods}

Materials. The following antibodies were used: IgG fraction of polyclonal rabbit anti-human von Willebrand factor (kindly provided by Dr. Z. Ruggieri, The Scripps Research Institute, La Jolla, CA); affinity purified rabbit anti-human recombinant PA antibody that identified a single 70-kD band on Western blotting of mouse lung extract (kindly provided by Dr. R. Schleef, The Scripps Research Institute, La Jolla, CA); polyclonal rabbit antisera raised against murine fibrinogen/fibrin (kindly provided by Dr. E. Plow, The Cleveland Clinic Foundation, Cleveland, $\mathrm{OH}$ ); polyclonal rabbit antisera raised against bovine muzzle epidermal keratin (Dako Co., Carpenteria, CA) (28); biotin-tagged goat anti-rabbit, goat anti-rat and mouse anti-goat IgG fraction (preabsorbed against murine serum proteins; Jackson Immunoresearch Laboratories, West Grove, PA); monoclonal rat anti-mouse macrophage protein (BM8; Bachem Bioscience, King of Prussia, PA); polyclonal goat antisera raised against murine vimentin (ICN Biomedicals Inc., Costa Mesa, CA) and polyclonal rabbit antisera raised against chicken desmin (Sigma Chemical Co., St. Louis, MO).

cDNA templates used for experiments described in this manuscript are as follows: a 1,085-bp EcoR1/Sphl fragment of murine PAI-1 (kindly provided by Dr. L. Diamond, Princeton University, Princeton, NJ) (29), subcloned into pGEM-3Z (Promega Corp., Madison, WI); an 821-bp Smal/Sacl fragment of a full length murine TF in pGEM$3 Z$ and pGEM-4Z (30); an 804-bp PstI/XbaI fragment of rat dehydrogenase (American Type Culture Collection, Rockville, MD) (31), subcloned into pGEM-3Z; a 2,519-bp EcoR1 fragment of murine tissuetype plasminogen activator in pKS \pm (kindly provided by Dr. S. Strickland, SUNY at Stony Brook, Stony Brook, NY) (32), and a 1,076-bp $\mathrm{XbaI} / \mathrm{HindIII}$ fragment of murine urokinase (also kindly provided by Dr. S. Strickland), subcloned into pGEM-3Z.

Animal experimentation. All animal protocols were approved by The Scripps Research Institute's Committee on Animal Investigation (Protocol \#ARC-39SEP02). 7-10-wk-old, female, pathogen-free, C57B1/6 mice were anesthetized with methoxyflurane (Pitman-Moore Inc., Mundelein, IL) and then treated with bleomycin. Briefly, the tra- chea was exposed using sterile technique and either $4 \mathrm{U} / \mathrm{kg}$ of bleomycin sulfate (provided by D. Elliot, Bristol-Myers-Squibb Pharmaceuticals, Princeton, $\mathrm{NJ}$ ) in $0.9 \% \mathrm{NaCl}$ (Baxter Healthcare Corp., Deerfield, IL) or an equivalent volume of sterile $0.9 \% \mathrm{NaCl}$ was slowly instilled into the tracheal lumen. The skin wound was closed and the animals were allowed to recover. At various times thereafter, the mice were killed for tissue harvesting. Lung tissue was fixed in situ via tracheal insufflation with $0.1 \mathrm{M}$ phosphate buffered ( $\mathrm{pH} 7.4$ ) $4 \%$ paraformaldehyde (Sigma Chemical Co.) $\left(4^{\circ} \mathrm{C}, 20 \mathrm{~min}\right.$ ) at $25 \mathrm{~cm} \mathrm{H}_{2} \mathrm{O}$ pressure for immunohistochemical and in situ hybridization studies. Paraffin embedded, $3-\mu \mathrm{m}$ fixed tissue sections of the lungs of all animals were then placed on glass slides (Superfrost/Plus; Fisher Scientific Co., Pittsburgh, PA) for further analysis. For intermediate filament analysis, lungs were fixed in situ in inflation with O.C.T. (Baxter Healthcare Corp.) and $4 \mu \mathrm{m}$ cryostat sections were mounted on coated glass slides.

Immunohistochemical analysis. Immunohistochemical analysis was performed by minor modifications of the commercially available indirect avidin-biotin-peroxidase procedure (Zymed Laboratories, Inc., S. San Francisco, CA) as described previously (33). Briefly, the tissue was deparaffinized in xylene, rehydrated, and incubated in $3 \% \mathrm{H}_{2} \mathrm{O}_{2}$ in methanol to inhibit endogenous peroxidase activity. After additional blocking with $10 \%$ heat inactivated goat serum, the primary antibody was applied and the tissue was incubated overnight at $4^{\circ} \mathrm{C}$. After incubation, the biotin-tagged secondary IgG and streptavidin-peroxidase complex were sequentially applied to the tissue sections for $30 \mathrm{~min}$. The antigen was visualized (i.e., by aminoethylcarbazole) as a red precipitate surrounded by a blue hematoxylin counterstain with bright field microscopy. Immunostaining of the same tissue with preimmune rabbit IgG was performed in parallel as a negative control. The polyclonal rabbit antisera directed toward murine fibrinogen identifies fibrin and all three chains of fibrinogen. All positive staining with this antibody is herein referred to as fibrin based on confirmatory electron microscopic surveys of glutaraldehyde-fixed lung tissue.

Direct and reverse fibrin autography. Direct and reverse fibrin autography was performed on lung tissue extracts after nonreducing SDSPAGE, as previously described $(34,35)$, and on frozen lung tissue sections (21). The lung tissue was removed from exsanguinated mice, finely minced, exhaustively washed in $4^{\circ} \mathrm{C}$ phosphate buffered saline, and snap-frozen in liquid nitrogen. Lung protein extracts were prepared by homogenization of lung tissue in $10 \mathrm{vol}(\mathrm{wt} / \mathrm{vol})$ of $1 \%$ SDS. Preliminary experiments revealed no differences in the extraction of PAs and PAI-1 by either $1 \%$ SDS or buffered 0.1 M KSCN (36). Equivalent volumes per lane were loaded on the SDS-polyacrylamide gel. For lung tissue sections, the overlay gel technique was adapted for use on 10$\mu \mathrm{m}$ frozen tissue sections based on a prior method used on human tissue (37). An agarose gel (final concentration, $0.83 \%$, Sea Plaque; FMC Bioproducts, Rockland, ME) containing purified human plasminogen ( final concentration, $8.3 \mu \mathrm{g} / \mathrm{ml}$ ), bovine fibrinogen (final concentration, $8 \mathrm{mg} / \mathrm{ml}$; Sigma Chemical Co.) and alpha-thrombin (final concentration, $0.5 \mathrm{U} / \mathrm{ml}$, kindly provided by Dr. J. Fenton, New York State Dept. of Health, Albany, NY) was cast at a thickness of $0.5 \mathrm{~mm}$ and placed on prewarmed tissue sections. The sections and overlay gel were incubated at $37^{\circ} \mathrm{C}$ for $1-2 \mathrm{~h}$ in a humidified chamber at which time they were photographed under indirect light. Preliminary experiments using this system revealed that amiloride (final concentration, $1 \mathrm{mM}$; Sigma Chemical Co.) (38) specifically inhibited the action of $3 \mathrm{IU} / \mathrm{cm}^{2}$ of a urokinase standard (National Institute for Biological Standards and Controls [NIBSC], London; reference 66/46), but did not affect the activity of t-PA; and that anti-t-PA IgG (final concentration, $10 \mu \mathrm{g}$ / $\mathrm{ml}$ ), but not preimmune IgG, specifically inhibited the action of $12 \mathrm{IU} /$ $\mathrm{cm}^{2}$ of single chain PA (NIBSC reference 83/517) but not that of the urokinase standard, when assayed over a 3-h period.

Northern blot analysis. Tissues destined for RNA extraction were harvested by dissection, finely minced, washed extensively with cold phosphate buffered saline, and snap-frozen in liquid nitrogen. Whole tissue RNA was extracted by the acid guanidium isothiocyanate-phenol chloroform method (39), and the concentration of total RNA was deter- 

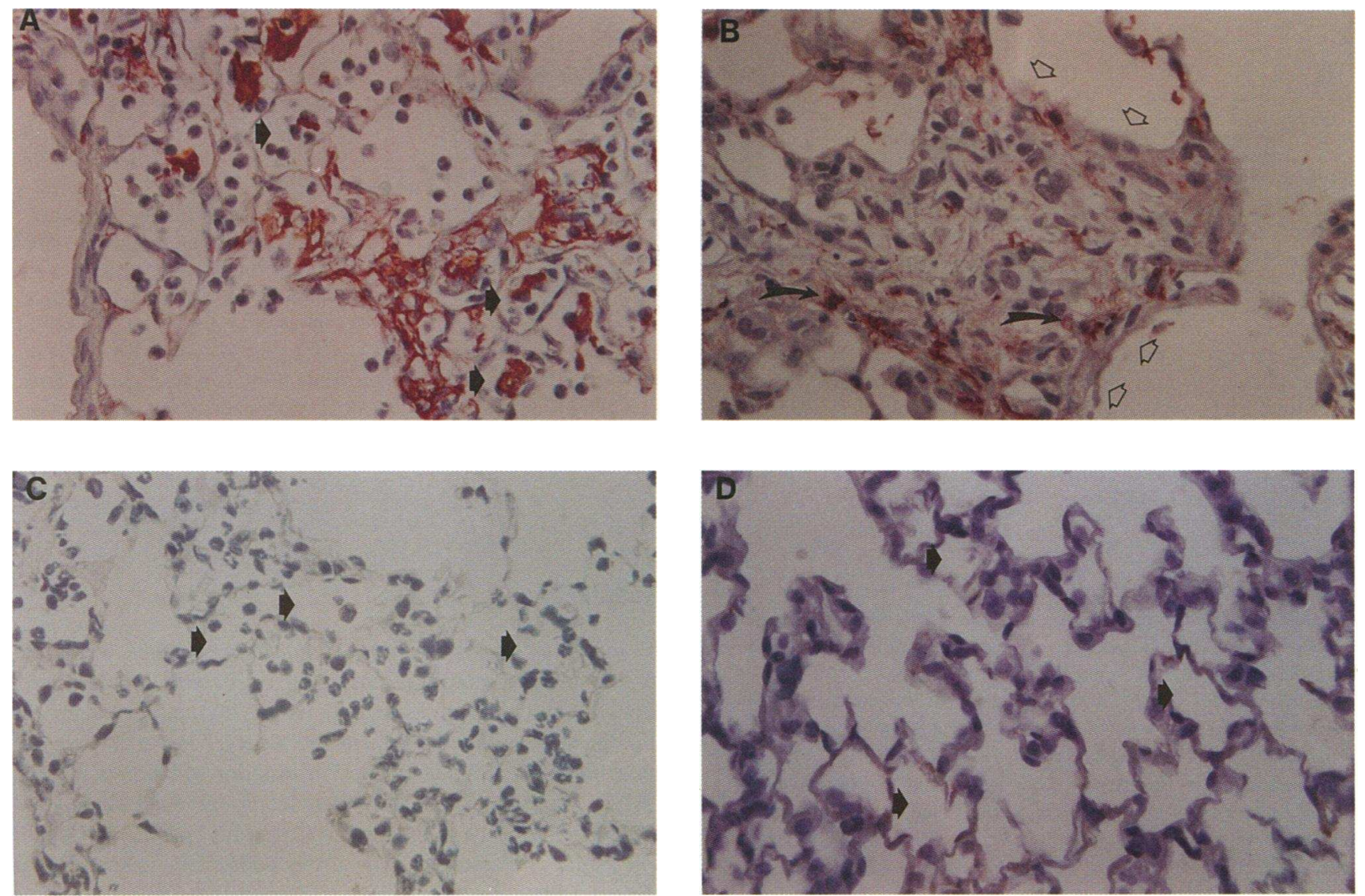

Figure 1. Localization of fibrin in lung tissue. Fixed tissue sections from the lungs of animals exposed to either bleomycin $(A-C)$ or saline $(D)$ were stained immunologically for fibrin (red precipitate) as described in Methods $(\times 400)$; Filled arrowheads indicate alveolar space, open arrowheads delineate fibroproliferative lesion, and curved arrows indicate fibrin in matrix. $(A)$ Acute alveolitis phase ( $8 \mathrm{~d}$ after IT bleomycin). (B) Fibroproliferative phase (14 d after IT bleomycin). (C) Acute alveolitis phase, preimmune serum control. $(D)$ Saline-instilled control $(8 \mathrm{~d})$.

mined by sample absorbance at $260 \mathrm{~nm}$. For Northern blotting, $30 \mu \mathrm{g}$ per lane of RNA was electrophoresed under denaturing conditions and transferred to nylon membranes $(0.2 \mu \mathrm{m}$ pore size, Biotrans; Pall Biosupport Corp., East Hills, NY) as described $(24,40)$. Equal loading and transfer of the RNA was verified by visualization of the ethidium bromide-stained RNA in the membrane after transfer. The membranes were soaked in $50 \mathrm{mM}$ Pipes buffer ( $\mathrm{pH} 6.8$ ) with 5\% SDS for $30 \mathrm{~min}$ and then hybridized with $10^{6} \mathrm{cpm}$ of radiolabeled probe per milliliter of Pipes/SDS solution for $16 \mathrm{~h}$ at $65^{\circ} \mathrm{C}$. The deoxyguanosine $5^{\prime}-[\alpha-$ ${ }^{32} \mathrm{P}$ ] triphosphate $(3,000 \mathrm{Ci} / \mathrm{mmol}$, Amersham Corp., Arlington Heights, IL) labeled DNA fragments were transcribed in vitro by random priming with the Klenow fragment of Escherichia coli DNA polymerase (Amersham Corp.) (41) to a sp act of $>1 \times 10^{8} \mathrm{cpm} / \mu \mathrm{g}$ DNA. The blots were then washed four times for $15 \mathrm{~min}$ each at $65^{\circ} \mathrm{C}$ with $5 \%$ SDS, $0.67 \times$ SSC. Autoradiography was performed at $-70^{\circ} \mathrm{C}$ in cassettes with intensifier screens on XAR- 5 film (Eastman Kodak Co., Rochester, NY). The intensity of the signal for specific mRNAs was quantified directly by using a radioanalytic image processor (AMBIS), and the signal from a specific mRNA species was normalized to the signal intensity for the 18S ribosomal RNA as described (24). In preliminary experiments, we confirmed the work of Hoyt et al., who showed an increase in the proportion of mRNA/total RNA in bleomycin-injured lungs (42), by demonstrating a two-fold increase in the signal for the two constitutively produced mRNAs (i.e., glyceraldehyde-3-phosphate dehydrogenase [G3PDH] and CHO:B [43]) in total RNA extracts of lungs injured by bleomycin 8 and $14 \mathrm{~d}$ earlier.

In situ hybridization. The radiolabeled probes used for these studies were prepared as described (40). Briefly, radiolabeled sense and antisense RNA were generated by in vitro transcription using SP6, T7, or T3 RNA polymerases (Promega Corp.) with uridine $5^{\prime}-\alpha-\left[{ }^{35} \mathrm{~S}\right]-$ thiotriphosphate ( $>1,200 \mathrm{Ci} / \mathrm{mmol}$, Amersham Corp.) from the linearized plasmids. The specificity of transcription was verified by the demonstration of a single major full length transcript after analysis by polyacrylamide gel electrophoresis. Before hybridization, the tissue sections were deparaffinized, hydrated, and postfixed in $4 \%$ phosphate buffered paraformaldehyde $\left(4^{\circ} \mathrm{C}, 10 \mathrm{~min}\right)$. After proteinase $\mathrm{K}$ digestion (final concentration, $1 \mu \mathrm{g} / \mathrm{ml}, 10 \mathrm{~min}$ at $23^{\circ} \mathrm{C}$ ), the slides were prehybridized in $50 \%$ buffered formamide for $1 \mathrm{~h}$ at $42^{\circ} \mathrm{C}$. For hybridization, 1.8 $\times 10^{6} \mathrm{cpm}$ of radiolabeled probe in $50 \%$ buffered formamide containing $2.5 \mathrm{mg} / \mathrm{ml}$ yeast tRNA carrier (Sigma Chemical Co.) was overlayed on the sections and they were incubated for an additional $16 \mathrm{~h}$ at $55^{\circ} \mathrm{C}$. The slides were washed in $2 \times \mathrm{SSC}(1 \times \mathrm{SSC}$ is $150 \mathrm{mM} \mathrm{NaCl} / 15 \mathrm{mM}$ $\mathrm{Na}$ citrate) and then treated with RNase A (final concentration, $10 \mu \mathrm{g}$ / $\mathrm{ml}$; Boehringer Mannheim Biochemicals, Indianapolis, IN) for $30 \mathrm{~min}$ at $23^{\circ} \mathrm{C}$. The sections underwent low $(2 \times \mathrm{SSC})$ and high $\left(60^{\circ} \mathrm{C}, 0.1\right.$ $\times$ SSC containing $\beta$-mercaptoethanol) stringency washes, and were dehydrated in graded alcohol containing $0.3 \mathrm{M}$ sodium acetate. The sections were coated with NTB-2 emulsion (Eastman Kodak Co.), incubated in the dark for $1-12 \mathrm{wk}\left(4^{\circ} \mathrm{C}\right)$, developed (D19; Eastman Kodak Co.) and counterstained with hematoxylin and eosin. Lung tissue was analyzed by counting $>500$ lesional or histologically normal lung parenchymal cells for each mRNA species per time point from saline and bleomycin-exposed lung tissue hybridized in parallel. A cell was defined as positive when $\geq 5$ perinuclear grains were detected (magnification 
A

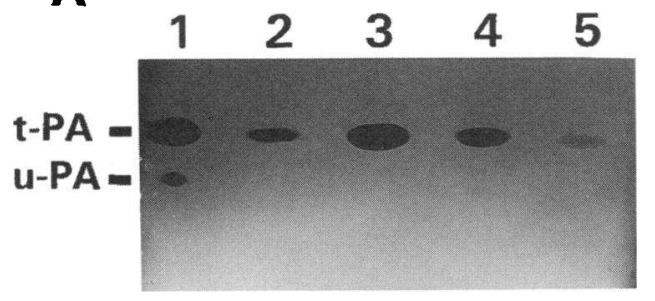

B

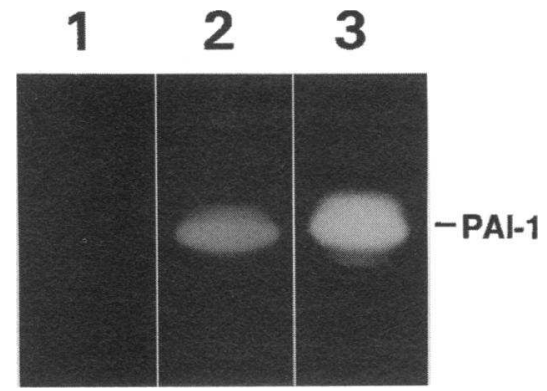

Figure 2. Characterization of the fibrinolytic components in normal and bleomycin-exposed lung tissue. Protein extracts were prepared from lung tissue taken from saline and bleomycin-treated animals, fractionated by electrophoresis under nonreducing conditions, and then analyzed by direct fibrin autography $(A)$ and reverse fibrin autography $(B)$. The dark areas in $A$ reflect the presence of

PAs, and the light areas in $B$ indicate inhibitor zones. $(A)$ Lane 1 , lung extract from saline-treated animal (14 d); Lanes $2-5$, lung extract from bleomycin-treated animals of $4,8,14$, and $21 \mathrm{~d}$, respectively. $(B)$ Lane 1 , lung extract from a representative saline-instilled animal; lane 2, lung extract from a representative bleomycin-instilled animal; lane 3, murine PAI-1 present in conditioned media ( $50 \mu \mathrm{l})$ from phorbol myristate acetatetreated $3 \mathrm{~T} 3$ cells.

320; average of bright and dark field signals). 12 serial sections were examined per specific mRNA for each time point. As a control, sense transcripts on the same tissue were processed in parallel. Representative photomicrographs and cell tabulations are presented.

Statistical methods. A two-way analysis of variance was used on the quantitative data generated by radioanalytic scanning to and parenchymal cell counting to test for group differences in the hybridization signal over time in lung tissue from saline and bleomycin exposed animals. Where a significant difference was noted, a Student-NewmanKeuls multiple comparisons procedure was performed to test for differences at specific time points (44). Significance was accepted at a $P$ value of $<0.05$ for all analyses.

\section{Results}

Localization of fibrin in lung tissue. Experiments were performed to determine the time course of extravascular fibrin deposition in bleomycin-injured lungs. Immunohistochemical staining first revealed fibrin in the alveolar space in areas of acute alveolitis at $8 \mathrm{~d}$ after the IT instillation of bleomycin (Fig. $1 A$ ). In a subsequent electron microscopic survey of bleomycinexposed lung tissue, polymerized fibrin was specifically identified by its characteristic $20-30 \mathrm{~nm}$ periodicity in these areas of acute alveolitis (not shown). During the fibroproliferative
A

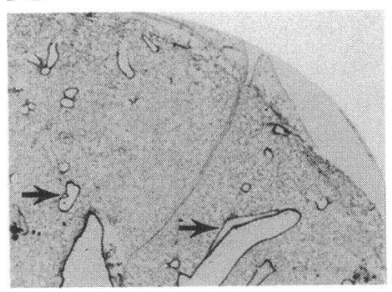

B

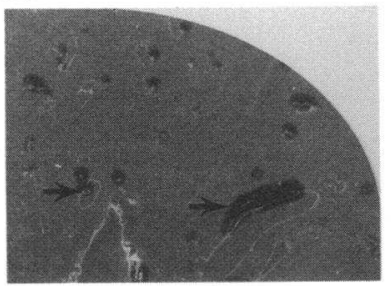

E

D

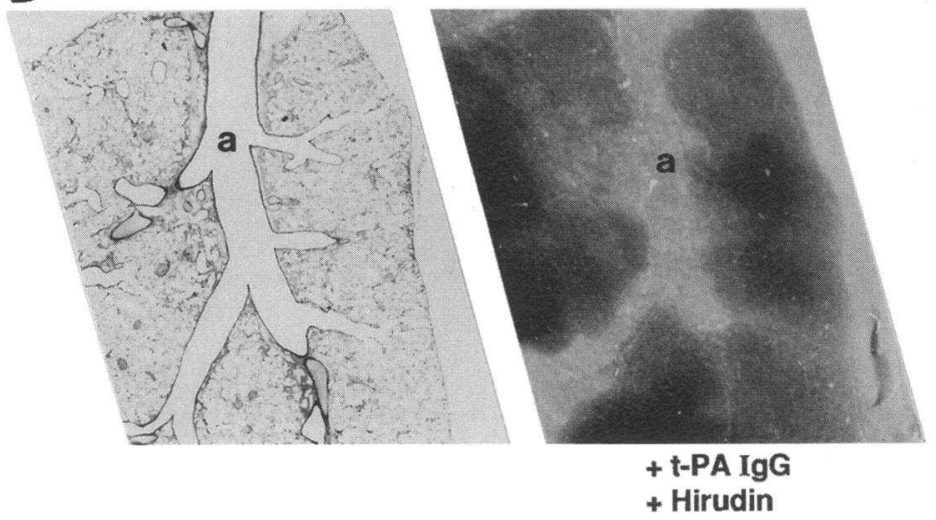

C

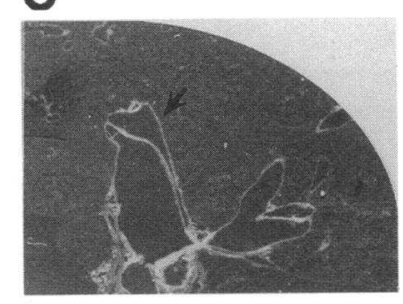

+ t-PA IgG

$\mathbf{F}$

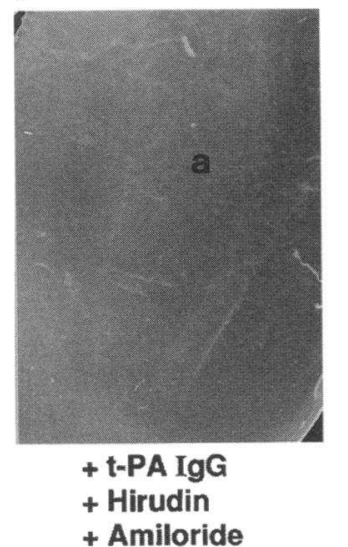

Figure 3. Localization of the fibrinolytic activity of normal lung tissue. Frozen lung tissue sections $(10 \mu \mathrm{m})$ from untreated mice were stained with hematoxylin $(A$ and $D$ ) or were incubated at $37^{\circ} \mathrm{C}$ in a humidified chamber for 3-8 $\mathrm{h}$ in contact with a fibrin/agar gel containing the indicated additives $(B, C, E$, and $F)$ and as described in Methods $(\times 4)$. Dark areas reflect fibrinolytic activity. $(A) \mathrm{He}-$ matoxylin-stained lung tissue section. Arrows indicate vascular structures which also immunostained for vWF antigen (not shown). (B) Serial section, analyzed by fibrin overlay method. Arrows show fibrinolytic activity associated with discrete vascular structures. $(C)$ Adjacent section analyzed by the fibrin overlay method in the presence of $10 \mu \mathrm{g}$ / $\mathrm{ml}$ anti-t-PA IgG (+t-PA IgG). Arrow indicates vascular structures. (D) Hematoxylin-stained lung tissue section showing lung parenchyma surrounding a bronchial lumen $(a)$. $(E)$ Serial

section, analyzed by the fibrin overlay method in the presence of anti t-PA IgG and hirudin. $(F)$ Adjacent section analyzed by the fibrin overlay method in the presence of amiloride, anti t-PA IgG, and hirudin. 
Table I. Quantitative Analysis of the Effect of Bleomycin on Total and Specific Pulmonary RNAs

\begin{tabular}{|c|c|c|c|c|c|c|}
\hline & \multirow{2}{*}{$\begin{array}{l}\text { Yield of total } \\
\text { RNA }(\mu \mathrm{g})\end{array}$} & \multirow{2}{*}{$\begin{array}{l}\text { Fold increase } \\
\text { in RNA yield }\end{array}$} & \multicolumn{4}{|c|}{ Fold induction of specific mRNAs } \\
\hline & & & TF & PAI-1 & u-PA & t-PA \\
\hline Saline & $134(26)$ & 1.0 & 1.0 & 1.0 & 1.0 & 1.0 \\
\hline \multicolumn{7}{|c|}{ Bleomycin } \\
\hline \multicolumn{7}{|c|}{ Time (d) } \\
\hline 1 & $141(4)$ & 1.1 & $2.3(0.8)$ & $2.0(0.4)$ & $1.5(0.2)$ & $1.1(0.2)$ \\
\hline 4 & $193(49)^{*}$ & 1.4 & $3.8(0.3)^{\ddagger}$ & $4.0(0.8)$ & $2.8(0.9)^{*}$ & $2.6(0.7)^{*}$ \\
\hline 8 & $362(127)^{\ddagger}$ & 2.7 & $5.0(1.8)^{8}$ & $4.5(1.6)^{*}$ & $2.9(0.8)^{\ddagger}$ & $2.1(0.6)$ \\
\hline 14 & $345(60)^{\ddagger}$ & 2.6 & $4.0(1.6)^{\ddagger}$ & $5.4(3.2)^{\ddagger}$ & $1.9(0.3)$ & $3.5(0.9)^{8}$ \\
\hline 21 & $230(107)^{*}$ & 1.7 & $1.4(0.6)$ & $1.8(0.6)$ & $2.0(0.7)$ & $0.9(0.4)$ \\
\hline
\end{tabular}

Total RNA yield was determined by sample absorbance at $260 \mathrm{~nm}$. The fold-induction of specific mRNAs was quantified by direct $\beta$-scanning of the ${ }^{32} \mathrm{P}$-cDNA, hybridized nylon membrane (see Methods). Values presented are those obtained by direct normalization to the values from the saline exposed lungs at the same time point after correction for inequalities in loading and transfer (i.e., by changes in the relative signals for $18 \mathrm{~S}$ ribosomal RNA). Pulmonary RNA from at least three animals per intervention per time point are included. Data are presented as mean with SD in parentheses. ${ }^{*} P<0.05 ;{ }^{\ddagger} P<0.01 ;{ }^{8} P<0.001$.

phase of the injury (i.e., 14 and $21 \mathrm{~d}$ after IT bleomycin), the fibrin immunohistochemical staining localized to areas of the extracellular matrix of fibroproliferative lesions (Fig. $1 B$ ). No staining was apparent when serial sections from bleomycin- treated animals were analyzed using preimmune serum (Fig. $1 C$ ) and fibrin was not detected in the lung parenchyma of control animals that received IT saline (Fig. 1D).

The effects of bleomycin on the fibrinolytic components in
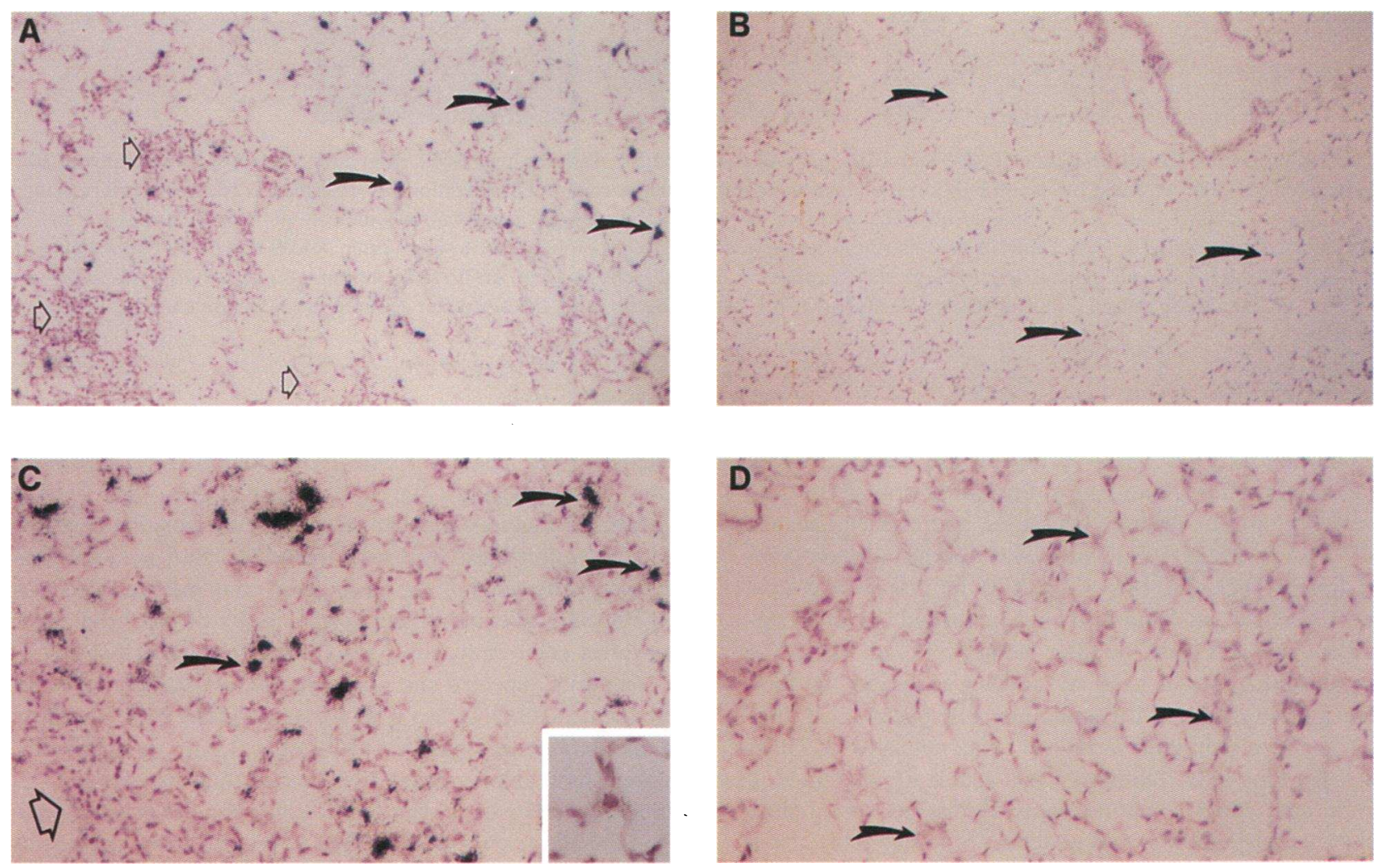

Figure 4. Localization of TF mRNA in lung tissue from animals exposed to bleomycin. Fixed lung tissue sections were analyzed by in situ hybridization for TF mRNA as described in Methods. Representative bright field photomicrographs are presented. Open arrows delineate areas of alveolitis $(A)$ or a fibroproliferative lesion $(C)$. Curved arrows indicate alveolar septal cells. $(A)$ Lung tissue section from an animal instilled with bleomycin $8 \mathrm{~d}$ earlier. The black dots in these photographs represent the actual hybridization signal $(\times 100)$. $(B)$ Lung tissue from a saline $(8 \mathrm{~d})$ exposed control $(\times 100)$. (C) Lung tissue from a bleomycin-exposed animal $(14 \mathrm{~d})(\times 200)$; (Inset $)$ Cuboidal, septal-junction TF mRNA expressing cell, plane of focus is cell nucleus $(\times 1,000)$. $(D)$ Lung tissue from a bleomycin-exposed animal $(14 \mathrm{~d})$, but showing absence of TF mRNA signal in an area without a fibroproliferative lesion. 

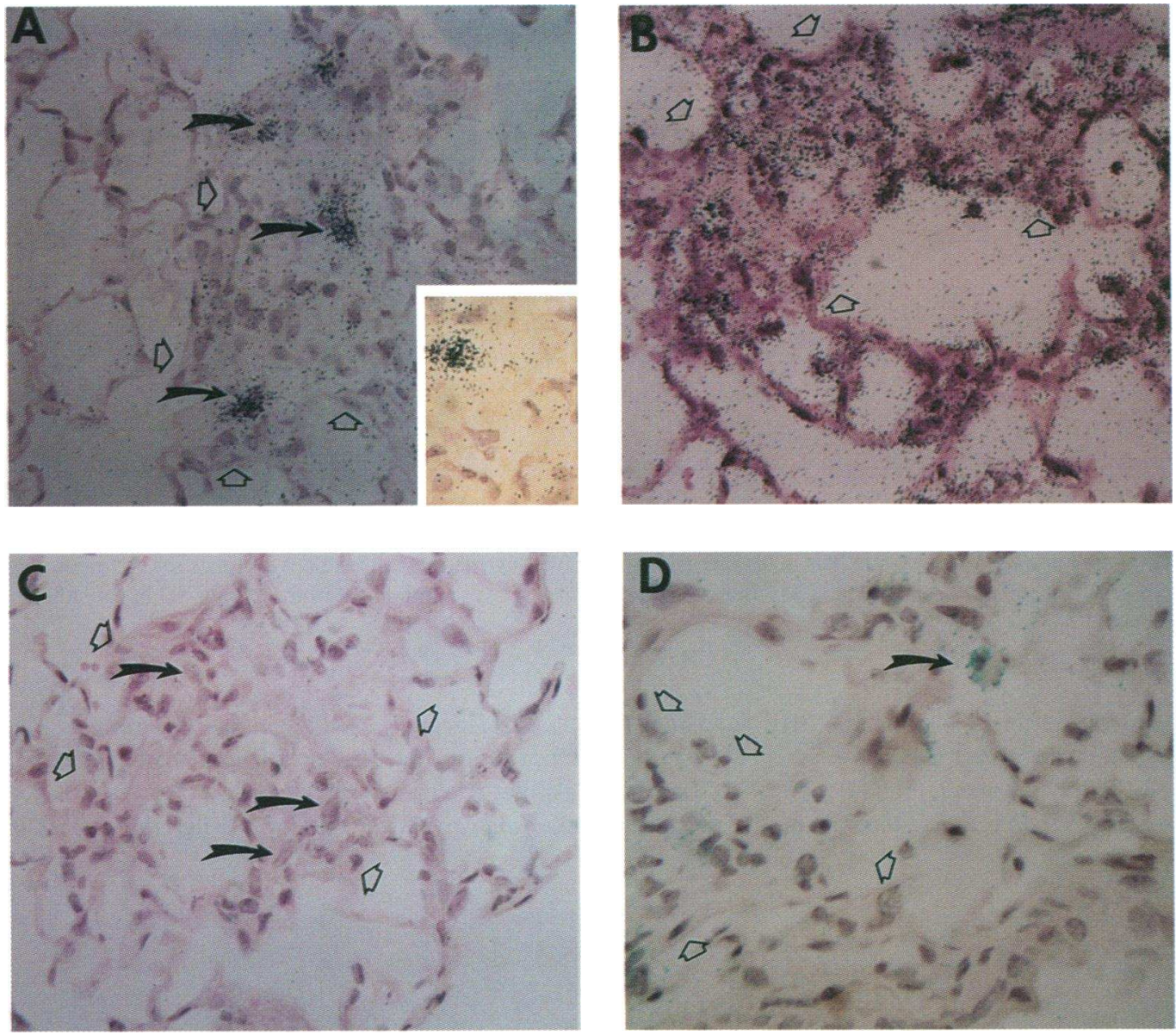

Figure 5. Comparison of the distribution of PAI-1 and u-PA mRNAs with that of G3PDH in lung tissue from animals exposed to bleomycin $14 \mathrm{~d}$ previously. Sections were analyzed by in situ hybridization and photographed under bright field conditions as described in Methods. Hybridization signal is indicated by black dots, $\times 400$. Open arrowheads delineate fibroproliferative lesions, curved arrows indicate positive cells in $A, C$, and $D$. $(A)$ Hybridization with antisense PAI-1 mRNA reveals several positive cells in a fibroproliferative lesion; $($ Inset, $\times 1,000)$. (B) Hybridization with antisense G3PDH mRNA reveals generalized, homogeneous expression from all cells in a fibroproliferative lesion. $(C)$ Control hybridization of a fibroproliferative lesion with sense G3PDH mRNA. (D) Hybridization with antisense u-PA mRNA under epiluminescent conditions. Signal appears as green dots.

murine lungs. The fibrinolytic components present in whole lung protein extracts and tissue sections were characterized by direct and reverse fibrin autography. Standard fibrin autography gels were run on four separate occasions, and in each instance the u-PA $\left(M_{\mathrm{r}}=45 \mathrm{kD}\right)$ lytic zone was absent in bleomycininjured lungs. The t-PA $\left(M_{\mathrm{r}}=70 \mathrm{kD}\right)$ lytic zone was also consistently reduced at 4 and $21 \mathrm{~d}$ but approached that of salineinstilled animals at 8 and $14 \mathrm{~d}$ after bleomycin (Fig. $2 \mathrm{~A}$ ). The identity of these zones as t-PA and u-PA was verified by their selective inhibition with t-PA antibodies $(10 \mu \mathrm{g} / \mathrm{ml})$ and amiloride, respectively, in the overlay gel (data not shown). Panel $B$ shows that lung PAI-1 activity was dramatically increased in bleomycin injured lungs over the entire 21-d period tested (Fig. $2 B$, lane 2 ). This inhibitor comigrated with murine PAI-1 from phorbol myristate acetate-stimulated $3 T 3$ cells (Fig. $2 B$, lane 3) (33).

When frozen lung tissue sections from animals exposed to saline were incubated under fibrin gels, fibrinolytic activity was detected over vascular structures (Fig. 3, $A$ and $B$ ). These structures were identified based on their immediate peribronchial location, relative size, and their positive staining with antibodies to vWF (data not shown). The vascular proteolytic activity is related to t-PA since it is selectively inhibited by antibodies against this molecule (Fig. $3 \mathrm{C}$ ). Furthermore, t-PA antigen colocalized immunohistochemically to vWF-positive endothelial cells within these structures (data not shown). No u-PA activity was detected by the basic gel overlay method. This lack of u-PA activity could be due to the ability of the thrombin in the overlay gel to irreversibly inactivate single chain u-PA (45). We therefore repeated the experiments using fibrin gels that were incubated before use with a fivefold molar excess of hirudin, an active site inhibitor of thrombin. Using this approach, we were now able to detect generalized lung parenchymal fibrinolytic activity (i.e., dark areas; Fig. $3 E$ ) that was not obvious in the absence of hirudin. This activity was not affected by antibodies to t-PA but was inhibited by amiloride (Fig. $3 F$ ). The sensitivity of this PA activity to small amounts of thrombin, and its selective inhibition with amiloride, suggest that this parenchymal proteolytic activity results from the presence of single chain u-PA (scu-PA). Lesional PA or PAI-1 activity could not be assessed due to the low level of resolution of this technique for parenchymal scu-PA, and the presence of 


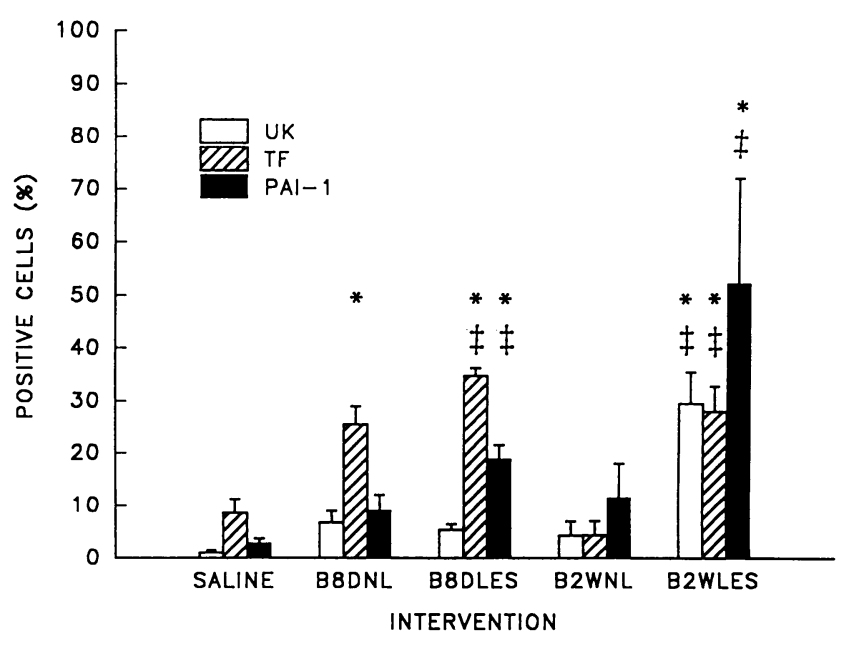

Figure 6. Quantitative localization of TF, UK, and PAI-1 mRNA expressing cells. Lung tissue was hybridized with specific probes and tabulated as described in Methods. The percent (mean \pm SD) of $\geq 500$ cells/tissue area/probe expressing $\geq 5$ grains per nucleus is plotted on the ordinate. Open bars represent u-PA mRNA, hatched bars represent TF mRNA, and solid bars represent PAI-1 mRNA. On the abscissa, SALINE refers to saline-instilled control; B8D and B2W refer to bleomycin-instilled 8 and $14 \mathrm{~d}$ lungs, respectively; NL refers to histologically normal lung while LES refers to histologically lesional areas of lung. ${ }^{*} P<0.01$ as compared with saline controls, ${ }^{\ddagger} P<0.01$ as compared with normal areas from the same tissue.

uncharacterized intravascular inhibitors. To quantitate and determine the localization of these molecules in relation to lesional tissue in bleomycin-injured lungs, Northern blotting and in situ hybridization for these molecules were performed (see below).

Induction of fibrinolytic and procoagulant mRNA species by bleomycin. The time course of bleomycin-related induction of lung PAI-1, TF, u-PA, and t-PA mRNAs were determined by Northern blot analysis of whole lung RNA. The steady state levels of each of these specific mRNAs increased by $4 \mathrm{~d}$ after bleomycin lung injury, peaked at 8-14 d, when compared to the saline-instilled lungs, and declined towards baseline by 21 $\mathrm{d}$ after IT bleomycin (Table I). However, the induction of TF and PAI-1 mRNAs was quantitatively greater than that observed for the PAs. The total RNA content of these tissues also increased threefold during the same time, indicating that the absolute increase in the mRNAs for TF and PAI-1 was $~ 15$-fold. Neither the intensity of the signals for the specific mRNAs nor the total pulmonary RNA content varied in the saline-instilled mice over this time frame (Table I).

Analysis of lung tissue by in situ hybridization. To determine the cellular origin and localization of the induced mRNAs relative to lesional areas, in situ hybridization was performed on lung tissue from saline and bleomycin-exposed animals. Bleomycin lung injury resulted in a strong increase in the proportion of TF mRNA expressing cells in both normal and alveolitis areas at $8 \mathrm{~d}(8.6 \pm 2.6 \%$ [ for saline control] vs $26 \pm 3.5 \%$ [bleomycin normal areas] and $34.8 \pm 1.5 \%$ [bleomycin alveolitis areas ]; $P<0.0001$ ) (Fig. 4 and 6 ). During the fibroproliferative phase ( $14 \mathrm{~d}$ after bleomycin), the proportion of TF mRNA expressing cells increased only within the lesional areas (to $28 \pm 4.9 \%$ of cells positive; $P<0.0001$ ) over that of salineinstilled controls (Figs. 4 and 6 ). TF mRNA expression was also noted in the major bronchial epithelial cell layer in normal and bleomycin-injured lungs (data not shown).

In contrast, PAI-1-expressing cells were induced relative to saline controls, but specifically within involved areas of lung at both the alveolitis phase $(2.9 \pm 0.8 \%$ cells positive from saline vs $19.6 \pm 2.5 \%$ cells positive in alveolitis areas; $P<0.01$ ) and at the fibroproliferative lesional phase $(53 \pm 20 \%$ cells positive within lesion; $P<0.0001$ vs saline) (Fig. $5 A$; Fig. 6). In contrast to the focal induction of PAI-1 mRNA in specific lesional cells, a constitutively expressed mRNA (i.e., G3PDH) did not localize to specific cells or within the fibroproliferative lesions in injured lungs (Fig. $5 \mathrm{~B}$ ). Sense transcript controls from the same tissue that were hybridized in parallel failed to generate a hybridization signal (Fig. $5 C$ ). u-PA mRNA expressing cells also were increased within fibroproliferative lesions $(1.0 \pm 0.5 \%$ cells positive from saline vs $29.5 \pm 6 \%$ cells positive in lesion; $P<0.0001$ ) but only during the fibroproliferative phase at $14 \mathrm{~d}$ after bleomycin injury (Fig. $5 \mathrm{D}$; Fig. 6).

Intermediate filament expression of fibroproliferative lesional cells. The distribution of various intermediate filament expressing cells within fibroproliferative lesions was determined in an attempt to identify the lesional cells expressing TF, PAI-1, and u-PA mRNAs. Consistent with observations in the rat $(46),>90 \%$ of the fibroproliferative lesional cells expressed vimentin, while a fraction of those cells coexpressed BM-8 (i.e., macrophages) (Fig. 7, $A$ and $D$ ). Both desmin, a smooth muscle cell marker, and cytokeratin, an epithelial cell marker, were absent from the interior of the fibroproliferative lesions (Fig. 7, $B$ and $C$ ). Desmin-expressing cells were present only in vascular and bronchial wall smooth muscle cells, while cytokeratin was detected only at the periphery of lesions in alveolar epithelial lining cells (Fig. 7, B and C). Cytokeratin expression codistributed with cuboidal cells in alveolar septal junctions expressing high levels of TF mRNA ( $>50$ grains/ nucleus), supporting their type II epithelial identity. However, the $34 \%$ of lesional cells expressing TF mRNA must be a second, cytokeratin negative cell type, probably macrophages. The high level PAI-1 expressing cells codistributed with vimentin in cells with large nuclei and indistinct borders strongly supporting their fibroblastic origin. The high level u-PA mRNA expressing cells codistributed with BM-8 and were commonly found within the air space in cells with round eccentric nuclei, consistent with previous reports of $\mathrm{u}-\mathrm{PA}$ expression in monocytoid-macrophagic cells $(47,48)$ (Fig. 5 D).

\section{Discussion}

This study compares the expression of TF and components of the fibrinolytic system with the deposition of fibrin during the course of bleomycin-induced lung injury and repair in mice. Based on previous studies showing loss of vascular integrity in bleomycin lung injury (5), it is assumed that the fibrin itself is derived from coagulation of plasma fibrinogen as it traverses the blood-air interface. As TF accounts for the major fraction of normal and bleomycin-inducible alveolar fluid procoagulant activity $(17,18,26,49-52)$, it is highly likely that TF initiates alveolar coagulation of the plasma-derived fibrinogen. However, until recently, the sites of TF production in many tissues, including lung, have remained unknown.

Chronic injury-induced induction of lung parenchymal cell 

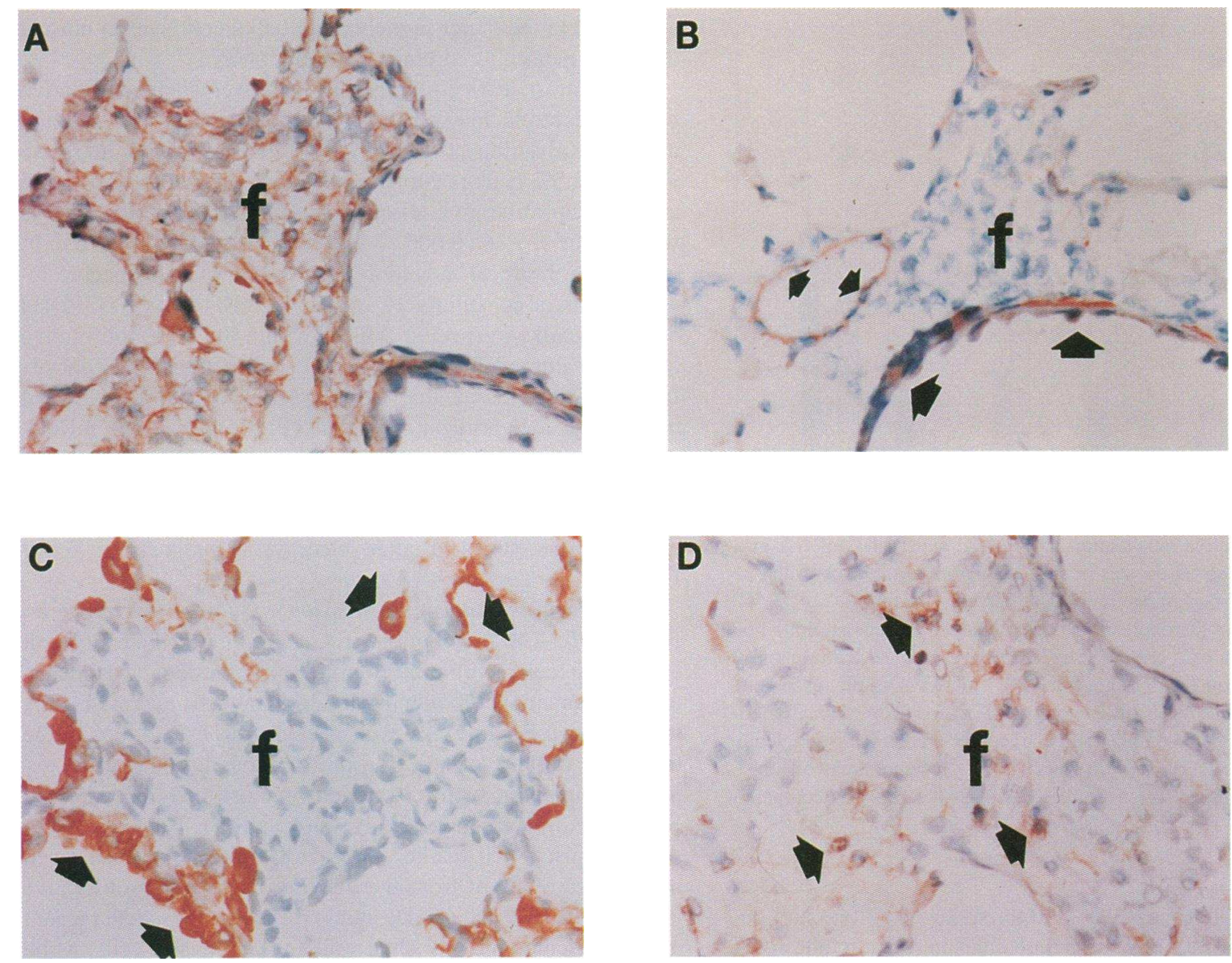

Figure 7. Intermediate filament staining of fibroproliferative lesions. Lung tissue was frozen in inflation and processed immunohistochemically with the indicated primary antibodies as described in Methods. Reddish-brown color indicates positivity $(\times 400)$. $\mathrm{f}$, fibroproliferative lesion. $(A)$ Antivimentin marks cells of mesenchymal cell lineage. $(B)$ Antidesmin marks cells of smooth muscle lineage. Note positive cells in vascular and bronchial walls (filled arrows). (C) Anticytokeratin marks selected cells of epithelial lineage at periphery of lesion (filled arrows). (D) Anti-BM8 marks selected cells of macrophage lineage (filled arrows).

TF mRNA in vivo is a novel finding. Our quantitative analysis of the TF mRNA distribution revealed an increase in TF mRNA expressing cells in fibrin-rich alveolitis areas and in fibrin-rich fibroproliferative lesions (Fig. 1) over that of saline-instilled controls, and over that of histologically normal areas from the same tissue section (Figs. 4 and 6). The observed increase in the percentage of TF positive cells in the fibrin-rich alveolitis regions grossly underestimates their relative lesional upregulation (four to fivefold), as the cell density of these regions increased (2.5-fold) due to lesional infiltration with TF negative neutrophils (Fig. 6). Taken together with the whole lung TF mRNA data (Table I), we conclude that TF mRNA was induced preceding and coincident with the deposition of alveolar and lesional fibrin in parenchymal cells from areas within and immediately adjacent to extravascular fibrin deposits.

Lesional TF mRNA producing cells codistribute with BM8 in areas that are devoid of cytokeratin thus supporting a macrophage origin. However, the morphology of perilesional TF mRNA expressing cells will not allow for distinction between macrophages and type II alveolar epithelial cells (Figs. 4 and 7). In our hands, epithelial cell TF mRNA expression was demonstrable in bronchial epithelium, and other investigators have observed TF production in type II alveolar epithelial cell lysates and in baboon lung tissue $(46,53,54)$. However, unequivocal confirmation of cell identities will await either double labeling or mRNA hybridization at the electron microscope level. Irrespective of the cell type, our key observation is the colocalization of TF mRNA expressing cells within fibrin-rich areas of alveolitis and fibroproliferative lesions. Lesional cell up-regulation of TF mRNA may be an important mechanism whereby local control is exerted over fibrin deposition.

Theoretically, the procoagulant action of lesional TF would support additional fibrin accumulation, if associated with local inhibition of the fibrinolytic system due to increased lesional PAI-1. As noted for TF mRNA, the actual PAI-1 mRNA cell concentration within alveolitis areas (i.e., $8 \mathrm{~d}$ ) is severalfold above that based on the quantitation of the percentage of positive lesional cells (Fig. 6). The whole lung and tissue overlay PA/PAI-1 activity assays suggest a PAI-1-dependent suppression of u-PA parenchymal activity despite the in situ hybridization findings of lesional up-regulation of both u-PA and PAI-1 mRNAs during the fibroproliferative phase (i.e., $14 \mathrm{~d}$ ). Together with the Northern blot findings, these in situ and activity observations colocalize excess PAI-1 activity and PAI-1 mRNA 
expressing cells to sites of fibrin accumulation within areas of alveolitis (i.e., $8 \mathrm{~d}$ ) and fibroproliferative lesions (i.e., $14 \mathrm{~d}$ ). The apparent up-regulation of u-PA mRNA within fibroproliferative lesions is indicative of a tight regulation of lesional proteolysis on a pericellular level in vivo. Although analysis of whole lung extracts by fibrin autography is a crude measure of pericellular proteolysis, the coordinated increase in PAI-1 activity (Fig. $2 B$ ), and suppression of u-PA activity (Fig. $2 A$ ) together with the apparent predominance of the relatively inactive single chain u-PA form suggests that the balance of the lesional plasminogen activator activity is inhibitory. These findings strongly support the idea that cells within the fibroproliferative lesions regulate their local fibrinolytic environment, and is consistent with our hypothesis that fibroblast-derived PAI-1 contributes to matrix fibrin persistance in the fibroproliferative lesions.

Although PAI-1 mRNA expression was induced in lesions, the possibility that plasma-derived PAI-1 contributes to the observed increase in total lung PAI-1 cannot be excluded. This is most relevant in the first week after injury when whole lung PAI-1 activity increased concomitant with submaximal increases in lung PAI-1 mRNA. However, exhaustive washing of minced tissue was performed to ensure removal of circulating plasma from the tissue before analysis, and neither PAI-1 protein or PAI-1 mRNA were detected in pulmonary vascular endothelial cells, thus supporting a critical role for locally produced PAI-1 and u-PA in the total PA and PAI-1 activities detected.

Prior studies suggest that airspace granulation tissue is a precursor to alveolar fibrosis $(1,2,55)$. Fibrin itself, as well as its soluble cleavage products are capable of modulating important processes that contribute to the formation of granulation tissue including mesenchymal cell adhesion and proliferation $(9-12)$. Since the distribution of fibrin seen in the bleomycin model parallels that of the putative site(s) of fibroblast proliferation and matrix deposition, a plausible argument can be made that the formation of the lesions may, in part, be a result of the effects of the persistence of extravascular fibrin. The factor(s) that modulate extravascular fibrin turnover may thereby affect the ultimate extent of fibrosis after lung injury. The lesional regulation of TF and PAI-1 synthesis or activity (56) may be one such modulatory mechanism. The inhibition of plasminmediated enzymatic degradation of matrix fibrin and matrix glycoproteins, and plasmin-mediated activation of procollagenase and $\operatorname{TGF} \beta(57,58)$ all are additional postulated mechanisms whereby inhibition of plasminogen activation by PAI- 1 can alter fibrinous matrix remodeling $(33,59,60)$. Recent in vivo work has underscored the importance of TGF $\beta$ for the pathogenesis of pulmonary fibrosis by demonstrating its potent matrix secretagogue activity in lung fibroblasts and by the ameliorating effect of neutralizing antibodies on bleomycin-induced pulmonary fibrosis $(42,61-66)$. Alternatively, lesional PAI-1 may act as a feedback loop negative regulator of TGF $\beta$ activity, as has been suggested in vitro (58). Future work will be directed towards defining the role of lesional fibroblast PAI-1 in the deposition and turnover of extracellular matrix after lung injury.

In conclusion, our analysis of bleomycin-injured murine lungs demonstrates a suppression of u-PA activity, a lesional upregulation of TF, u-PA, and PAI-1 mRNAs and the lesional deposition of fibrin. These data suggest that bleomycin injury results in a lesional hypercoagulable, hypofibrinolytic state which contributes to the initiation and maintenance of extravas- cular fibrin. Based on our data and current concepts of tissue repair, we propose that a PAI-1-mediated decrease in lesional fibrinolytic activity contributes to the outcome of tissue remodeling after bleomycin-induced lung injury in mice.

\section{Acknowledgments}

Dr. Olman would like to acknowledge the excellent technical assistance performed by Audrey Loftis and Kimberly Rivera.

Dr. Olman is a Parker B. Francis Foundation Research Fellow. This work was supported in part by a grant from the Alabama and California Chapters of the American Lung Association (M. A. Olman), and grants from the National Heart Lung and Blood Institute HL47819 (D. J. Loskutoff) and HL16411 (D. J. Loskutoff and N. Mackman).

\section{References}

1. Burkhardt, A. 1989. Alveolitis and collapse in the pathogenesis of pulmonary fibrosis. Am. Rev. Respir. Dis. 140:513-524.

2. Crouch, E. 1990. Pathobiology of pulmonary fibrosis. Am. J. Physiol. 259:L159-L184.

3. Bowden, D. H. 1984. Unraveling pulmonary fibrosis: the bleomycin model. Lab. Invest. 50:487-488.

4. Janick-Buckner, D., G. E. Ranges, and M. P. Hacker. 1989. Alteration of bronchoalveolar lavage cell populations following bleomycin treatment in mice. Toxicol. Appl. Pharmacol. 100:465-473.

5. Lindenschmidt, R. C., A. F. Tryka, G. A. Godfrey, E. L. Frome, and H. Witschi. 1986. Intratracheal versus intravenous administration of bleomycin in mice: acute effects. Toxicol. Appl. Pharmacol. 85:69-77.

6. Schrier, D. J., R. G. Kunkel, and S. H. Phan. 1983. The role of strain variation in murine bleomycin-induced pulmonary fibrosis. Am. Rev. Respir. Dis. 127:63-66.

7. Brown, L. F., B. Asch, V. S. Harvey, B. Buchinski, and H. F. Dvorak. 1987. Fibrinogen influx and accumulation of cross-linked fibrin in mouse carcinomas. Cancer. 1920-1925.

8. Dvorak, H. F., D. R. Senger, A. M. Dvorak, V. S. Harvey, and J. McDonaugh. 1985. Regulation of extravascular coagulation by microvascular permeability. Science (Wash. DC) 227:1059-1961.

9. Belew, M., B. Gerdin, J. Porath, and T. Saldeen. 1978. Isolation of vasoactive peptides from human fibrin and fibrinogen degraded by plasmin. Thromb. Res. 13:983-994.

10. Skogen, W. F., R. M. Senior, G. L. Griffin, and G. D. Wilner. 1988. Fibrinogen-derived peptide $\mathrm{B} \beta 1-42$ is a multidomained neutrophil chemoattractant. Blood. 71:145-149.

11. Senior, R. M., W. F. Skogen, G. L. Griffin, and G. D. Wilner. 1986. Effects of fibrinogen derivatives upon the inflammatory response: studies with human fibrinopeptide B. J. Clin. Invest. 77:1014-1019.

12. Bunce, L. A., L. A. Sporn, and C. W. Francis. 1992. Endothelial cell spreading on fibrin requires fibrinopeptide B cleavage and amino acid residues 15-42 of the $\beta$ chain. J. Clin. Invest. 89:842-850.

13. Limper, A. H., and J. Roman. 1992. A versatile matrix protein with roles in thoracic development, repair and infection. Chest. 101:1663-1673.

14. Kuhn, C., III, J. Boldt, T. E. King, Jr., E. Crouch, T. Vartio, and J. A. McDonald. 1989. An immunohistochemical study of architectural remodeling and connective tissue synthesis in pulmonary fibrosis. Am. Rev. Respir. Dis. 140:16931703.

15. Drake, T. A., J. H. Morrissey, and T. S. Edgington. 1989. Selective cellular expression of tissue factor in human tissues. Am. J. Pathol. 134:1087-1097.

16. Edgington, T. S., N. Mackman, K. Brand, and W. Ruf. 1991. The structural biology of expression and function of tissue factor. Thromb. Haemostasis. 66:6779.

17. McGee, M. P., and H. Rothberger. 1985. Tissue factor in bronchoalveolar lavage fluids. Am. Rev. Respir. Dis. 131:331-336.

18. Chapman, H. A., M. Stahl, C. L. Allen, R. Yee, and D. S. Fair. 1988. Regulation of the procoagulant activity within the bronchoalveolar compartment of normal human lung. Am. Rev. Respir. Dis. 137:1417-1425.

19. Chapman, H. A., C. L. Allen, and O. L. Stone. 1986. Abnormalities in pathways of alveolar fibrin turnover among patients with interstitial lung disease. Am. Rev. Respir. Dis. 133:437-444.

20. Blasi, F., J. Vassalli, and K. Dano. 1987. Urokinase-type plasminogen activator: Proenzyme, receptor, and inhibitors. J. Cell Biol. 104:801-804.

21. Sappino, A. P., J. Huarte, J. D. Vassalli, and D. Belin. 1991. Sites of synthesis of urokinase and tissue-type plasminogen activators in the murine kidney. J. Clin. Invest. 87:962-970. 
22. Loskutoff, D. J., M. Sawdey, and J. Mimuro. 1988. Type 1 plasminogen activator inhibitor. In Progress in Hemostasis Thrombosis. B. Coller, editor. W. B Saunders Co., Philadelphia. 87-115.

23. Vassalli, J., A. Sappino, and D. Belin. 1991. The plasminogen activator/ plasmin system. J. Clin. Invest. 88:1067-1072.

24. Sawdey, M., and D. J. Loskutoff. 1991. Regulation of murine type 1 plasminogen activator inhibitor gene expression in vivo. Tissue specificity and induction by lipopolysaccharide, tumor necrosis factor- $\alpha$, and transforming growth factor- $\beta$. J. Clin. Invest. 88:1346-1353.

25. Mackman, N., M. S. Sawdey, M. R. Keeton, and D. J. Loskutoff. 1993. Murine tissue factor gene expression in vivo: tissue and cell specificity and regulation by lipopolysaccharide. Am. J. Pathol. 143:76-84.

26. Idell, S., K. K. James, C. Gillies, D. S. Fair, and R. S. Thrall. 1989. Abnormalities of pathways of fibrin turnover in lung lavage of rats with oleic acid and bleomycin-induced lung injury support alveolar fibrin deposition. Am. J. Pathol. 135:387-399.

27. Chapman, H. A., Jr., P. Bertozzi, and J. J. Reilly, Jr. 1988. Role of enzymes mediating thrombosis and thrombolysis in lung disease. Chest. 93:1256-1263.

28. Steinert, P. M., and D. R. Roop. 1988. Molecular and cellular biology of intermediate filaments. Annu. Rev. Biochem. 57:593-625.

29. Prendergast, G. C., L. E. Diamond, D. Dahl, and M. D. Cole. 1990. The c-myc-regulated gene mrl encodes plasminogen activator inhibitor 1. Mol. Cell. Biol. 10:1265-1269.

30. Mackman, N., S. Imes, W. H. Maske, B. Taylor, A. J. Lusis, and T. A. Drake. 1992. Structure of the murine tissue factor gene. Arterioscler. Thromb. 1:373-382.

31. Yun Tso, J., X. Sun, T. Kao, K. S. Reece, and R. Wu. 1985. Isolation and characterization of rat and human glyceraldehyde-3-phosphate dehydrogenase cDNAs:genomic complexity and molecular evolution of the gene. Nucleic Acids Res. 13:2485-2501.

32. Rickles, R. J., and S. Strickland. 1988. Tissue plasminogen activator mRNA in murine tissues. FEBS Lett. 229:100-106.

33. Keeton, M., Y. Eguchi, M. Sawdey, C. Ahn, and D. J. Loskutoff. 1993. Cellular localization of type 1 plasminogen activator inhibitor mRNA and protein in murine renal tissue. Am. J. Pathol. 142:59-70.

34. Olman, M. A., J. J. Marsh, I. M. Lang, K. M. Moser, B. R. Binder, and R. R. Schleef. 1992. Endogenous fibrinolytic system in chronic large-vessel thromboembolic pulmonary hypertension. Circulation. 86:1241-1248.

35. Erickson, L. A., D. A. Lawrence, and D. J. Loskutoff. 1984. Reverse fibrin autography: a method to detect and partially characterize protease inhibitors after sodium dodecyl sulfate-polyacrylamide gel electrophoresis. Anal. Biochem. 137:454-463.

36. Camiolo, S. M., M. R. Siuta, and J. M. Madeja. 1982. Improved medium for extraction of plasminogen activator from tissue. Prep. Biochem. 12(4):297305.

37. Bernik, M. B., and H. C. Kwaan. 1969. Plasminogen activator activity in cultures from human tissues. An immunological and histochemical study. J. Clin. Invest. 48:1740-1753.

38. Vassalli, J. D. and D. Belin. 1987. Amiloride selectively inhibits the urokinase-like plasminogen activator. FEBS Lett. 214:187-191.

39. Chomczynski, P., and N. Sacchi. 1987. Single-step method of RNA isolation by acid guanidinium thyiocynate-phenol-chloroform extraction. Anal. Biochem. 162:156-159.

40. Schneiderman, J., M. S. Sawdey, M. R. Keeton, G. M. Bordin, E. F. Bernstein, R. B. Dilley, and D. J. Loskutoff. 1992. Increased type 1 plasminogen activator inhibitor gene expression in atherosclerotic human arteries. Proc. Natl. Acad. Sci. USA. 89:6998-7002.

41. Feinberg, A. P., and B. Vogelstein. 1983. A technique for radiolabeling DNA restriction endonuclease fragments to high specific activity. Anal. Biochem 132:6-13.

42. Hoyt, D. G., and J. S. Lazo. 1988. Alterations in pulmonary mRNA encoding procollagens, fibronectin and transforming growth factor- $\beta$ precede bleomycin-induced pulmonary fibrosis in mice. J. Pharmacol. Exp. Ther. 246:765-771.

43. Harpold, M. M. and R. M. Evans. 1979. Production of mRNA in chinese hamster cells: relationship of the rate of synthesis to the cytoplasmic concentration of none specific mRNA sequences. Cell. 1025-1035.

44. Zar, J. H. 1984. Biostatistical Analysis. Prentice-Hall, Inc. Englewood Cliffs, NJ. 718 pp.

45. Gurewich, V., and R. Pannell. 1987. Inactivation of single-chain urokinase (pro-urokinase) by thrimbin and thriombin-like enzymes: relevance of the findings to the interpretation of fibrin-binding experiments. Blood. 69:769-772.

46. Woodcock-Mitchell, J., K. B. Adler, and R. B. Low. 1984. Immunohisto- chemical identification of cell types in normal and in bleomycin-induced fibrotic rat lung. Am. Rev. Respir. Dis. 130:910-916.

47. Sitrin, R., P. Brubaker, J. Shellito, and H. Kaltreider. 1986. The distribution of procoagulant and plasminogen activator activities among density fractions of normal rabbit alveolar macrophages. Am. Rev. Respir. Dis. 133:468-472.

48. Chapman, H., Jr., O. Stone, and Z. Vavrin. 1984. Degradation of fibrin and elastin by intact human alveolar macrophages in vitro. J. Clin. Invest. 73:806815 .

49. Idell, S., B. T. Peterson, K. K. Gonzalez, L. D. Gray, R. Bach, J. Mclarty, and D. S. Fair. 1988. Local abnormalities of coagulation and fibrinoloysis and alveolar fibrin deposition in sheep with oleic acid-induced lung injury. Am. Rev. Respir. Dis. 138:1282-1294.

50. Idell, S., J. Peters, K. K. James, D. S. Fair, and J. J. Coalson. 1989. Local abnormalities of coagulation and fibrinolytic pathways that promote alveolar fibrin deposition in the lungs of baboons with diffuse alveolar damage. J. Clin. Invest. $84: 181-193$

51. Sitrin, R. G., P. G. Brubaker, and J. C. Fantone. 1987. Tissue fibrin deposition during acute lung injury in rabbits and its relationship to local expression of procoagulant and fibrinolytic activities. Am. Rev. Respir. Dis. 135:930938.

52. Idell, S., K. K. James, E. G. Levin, B. S. Schwartz, N. Manchanda, R. J. Maunder, T. R. Martin, J. Mclarty, and D. S. Fair. 1989. Local abnormalities in coagulation and fibrinolytic pathways predispose to alveolar fibrin deposition in the adult respiratory distress syndrome. J. Clin. Invest. 84:695-705.

53. Gross, T. J., R. H. Simon, and R. G. Sitrin. 1992. Tissue factor procoagulant expression by rat alveolar epithelial cells. Am. J. Respir. Cell Mol. Biol. 6:397-403.

54. Drake, T., J. Cheng, A. Chang, and F. J. Taylor. 1993. Expression of tissue factor, thrombomodulin, and E-selectin baboons with lethal Escherechia coli sepsis. Am. J. Pathol. 142:1458-1470.

55. Aso, Y., K. Yoneda, and Y. Kirrawa. 1976. Morphologic and biochemical study of pulmonary changes induced by bleomycin in mice. Lab. Invest. 35:558568 .

56. Seiffert, D., and D. J. Loskutoff. 1991. Kinetic analysis of the interaction between type 1 plasminogen activator inhibitor and vitronectin and evidence that the bovine inhibitor binds to a thrombin-derived amino-terminal fragment of bovine vitronectin Biochim. Biophys. Acta. 1078:23-30.

57. Liotta, L. A., R. H. Goldfarb, R. Brundage, G. P. Siegal, V. Terranova, and S. Garbisa. 1981. Effect of plasminogen activator (urokinase), plasmin, and thrombin on glycoprotein and collagenous components of basement membrane. Cancer Res. 41:4629-4636.

58. Sato, Y., and D. B. Rifkin. 1989. Inhibition of endothelial cell movement by pericytes and smooth muscle cells: activation of a latent transforming growth factor-b-like molecule by plasmin during co-culture. J. Cell Biol. 109:309-315.

59. Laiho, M., O. Saksela, and J. Keski-Oja. 1987. Transforming growth factor- $\beta$ induction of type 1 plasminogen activator inhibitor. J. Biol. Chem. 262:17467-17474.

60. Lund, L. R., A. Riccio, P. A. Andreasen, L. S. Nielsen, P. Kristensen, M. Laiho, O. Saksela, F. Blasi, and K. Dano. 1987. Transforming growth factor- $\beta$ is a strong and fast acting positive regulator of the level of type-1 plasminogen activator inhibitor mRNA in WI-38 human lung fibroblasts. EMBO (Eur. Mol. Biol. Org.) J. 6:1281-1286.

61. Ignotz, R. and J. Massague. 1986. Transforming growth factor- $\beta$ stimulates the expression of fibronectin and collagen and their incorporation into the extracellular matrix. J. Biol. Chem. 261:4337-4345.

62. Keski-Oja, J., R. Raghow, M. Sawdey, D. J. Loskutoff, A. E. Postlethwaite, A. H. Kang, and H. L. Moses. 1988. Regulation of mRNAs for type-1 plasminogen activator inhibitor, fibronectin, and type 1 pro collagen by transforming growth factor- $\beta$. J. Biol. Chem. 263:3111-3115.

63. Ignotz, R. A., T. Endo, and J. Massague. 1987. Regulation of fibronectin and type I collagen mRNA levels by transforming growth factor- $\beta$. J. Biol. Chem. 262:6443-6446.

64. Broekelmann, T. J., A. H. Limper, T. V. Colby, and J. A. McDonald. 1991. Transforming growth factor $\beta 1$ is present at sites of extracellular matrix gene expression in human pulmonary fibrosis. Proc. Natl. Acad. Sci. USA 88:6642-6646.

65. Khalil, N., O. Bereznay, M. Sporn, and A. H. Greenberg. 1989. Macrophage production of transforming growth factor $\beta$ and fibroblast collagen synthesis in chronic pulmonary inflammation. J. Exp. Med. 170:727-737.

66. Raghow, R., S. Lurie, J. M. Seyer, and A. H. Kang. 1985. Profiles of steady state levels of messenger RNAs coding for type 1 procollagen, elastin, and fibronectin in hamster lungs undergoing bleomycin-induced interstitial pulmonary fibrosis. J. Clin. Invest. 76:1733-1739. 